\title{
Capilla de la Nación Genovesa en la Catedral Vieja de Cádiz. Propuesta de intervención global para la consolidación, restauración y conservación preventiva de su retablo
}

\author{
María Campoy \\ Historia del Arte \\ Pedro Rodríguez \\ Jefe del Departamento \\ Departamento de Investigación \\ Centro de Intervención del I.A.P.H.
}

\section{Antecedentes}

Para la elaboración del presente proyecto de intervención del Retablo de los Genoveses, se ha partido del examen de los estudios realizados con anterioridad a la incorporación del I.A.P.H. a esta tarea. Estos son "Recomendaciones previas al proyecto de intervención en la Capilla de los Genoveses de la Iglesia de Santa Cruz (antigua catedral), Cádiz.", fechado en septiembre de 1994 y "Estudio de la Capilla de los Geno- veses de la Iglesia de Santa Cruz de Cádiz", de 1995. Esta información se ha contrastado con las posteriores y reiteradas visitas a la capilla y su entorno, incluyendo sus fosas de enterramiento, completándose con los siguientes informes: geológico, climatológico, arquitectónico e histórico-artístico.

Los desarrollos de estas actuaciones se han englobado en el proyecto denominado "Intervención global para la consolidación, restauración y conservación preventiva del Retablo de los Genoveses" que se encuentra actualmente en fase de redacción y cuyas líneas básicas se exponen a continuación.

\section{Un retablo italiano en Cádiz}

El Retablo de los Genoveses significó el punto de partida de una modalidad que ha contribuido a la individualización de Cádiz dentro del territorio anda-

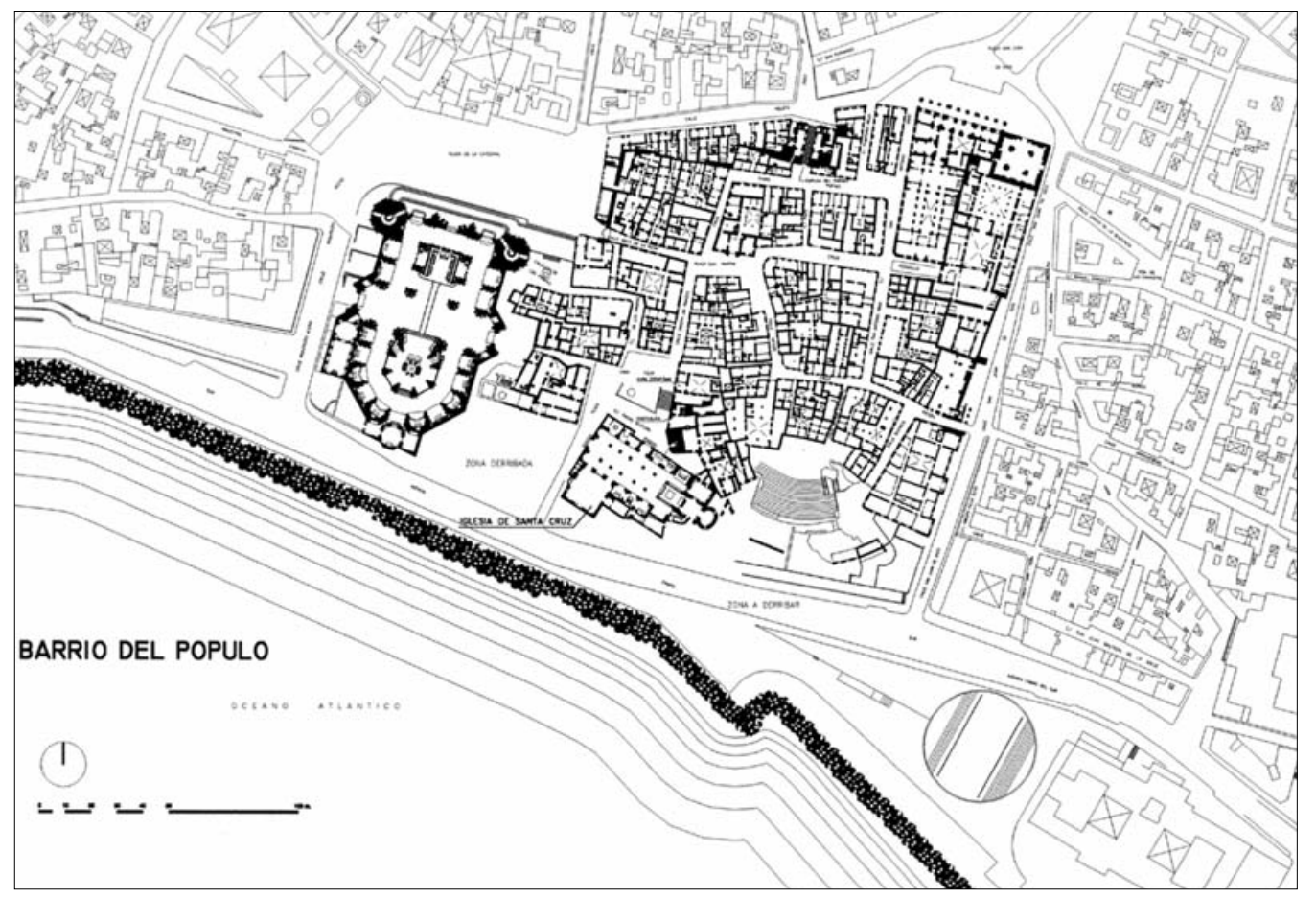

I. El Barrio del Pópulo de Cádiz con las catedrales Vieja y Nueva. (Oficina del Plan URBAN) 
0
$上$
2
$\Sigma$
$\vdots$
0
0
0
0

luz. Al no haber constancia de otras obras de estas características anteriores a 167I, año de su edificación según reza en la inscripción localizada en las repisas de sus hornacinas, la consideramos la primera de su especie que se realiza en Cádiz!.

Las palabras de Hipólito Sancho de Sopranis dan cuenta de la importancia de esta obra y de su repercusión social en la época. Aunque la presencia de mármoles genoveses en la región venía de antiguo, el impacto de esta obra se tradujo en la aparición de una nueva clientela que, al margen del ámbito genovés, demanda obras en mármol más por ostentación que por interés artístico, frente los acostumbrados retablos de madera dorados ${ }^{2}$.

La capilla genovesa fue fundada en la Catedral Vieja

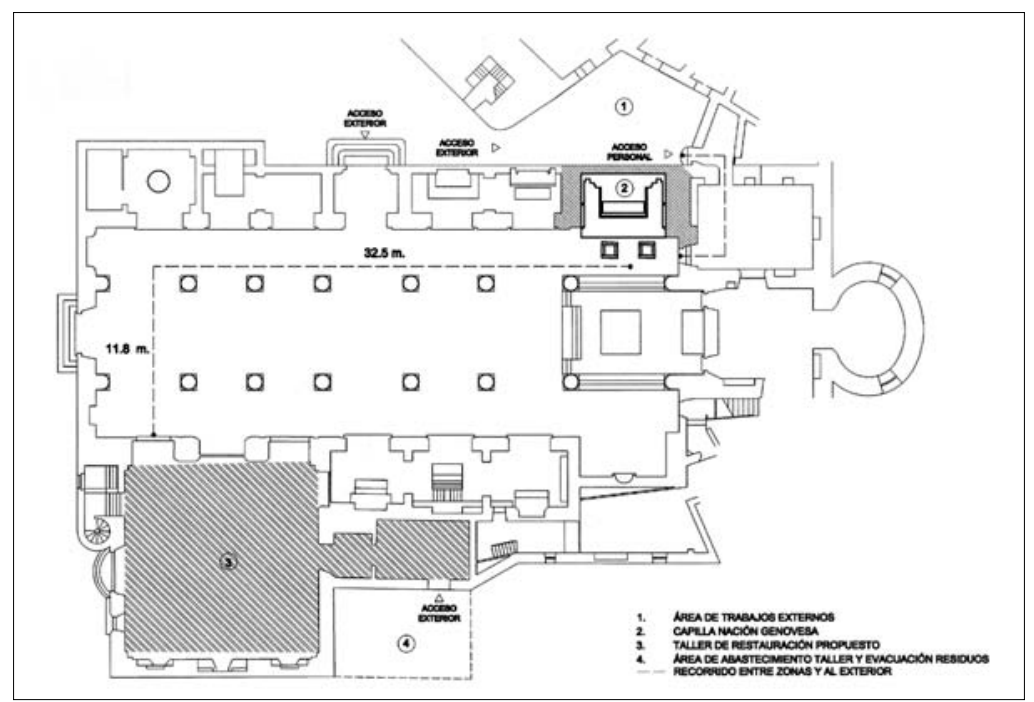

2. Situación de la Capilla de la Nación Genovesa en la iglesia de la Santa Cruz, catedral vieja de Cádiz, y zona propuesta para ubicar los talleres de restauración de elementos pétreos, (Plan URBAN y estudio MLM\&PRP)

3. Sección transversal de la Capilla, mostrando el corte de las criptas de enterramiento y el alzado frontal del retablo, (estudio MLM\&PRP)

4. Sección longitudinal de la Capilla mirando hacia el Sureste, (estudio MLM\&PRP)

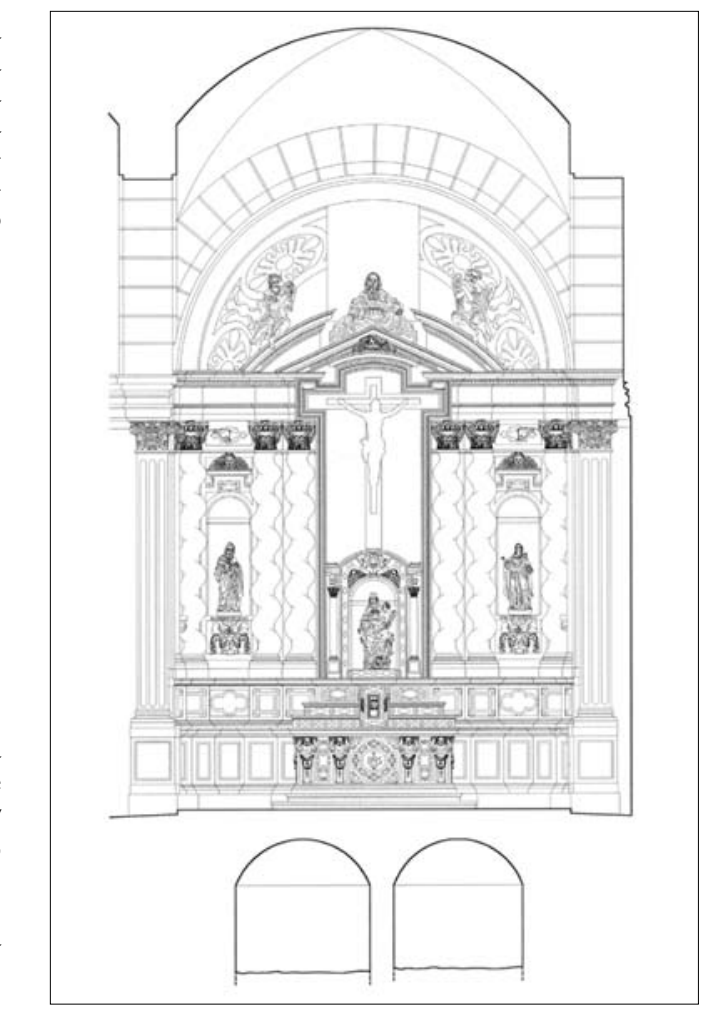

de Cádiz en 1487 por iniciativa de mercader genovés Francesco Usodimare, quien la adquirió con el beneplácito del obispo Pedro Fernández de Solís. Dedicada a Santa María y al patrón de la señoría ligur San Jorge, tenía uso como enterramiento de los nacionales y para la celebración de sus fiestas.

A raíz de los desastres ingleses de 1596 y las posteriores obras de restauración de la Catedral Vieja, el cabildo decide dotar al templo con un nuevo retablo mayor, eliminado por el obispo García de Haro años atrás para colocar en su lugar un coro al estilo italiano. El nuevo proyecto, ejecutado por el maestro Alejandro de Saavedra, dejaba fuera de la composición la imagen de un antiguo crucificado que hasta entonces había presidido el altar. Por la devoción popular que se le profesaba, el cabildo optó por donarla a alguna de las capillas vecinas, yendo a parar a la de los genoveses.

Constatado el depósito de la imagen con carácter perpetuo, el colectivo genovés se compromete en prueba de gratitud, a ejecutar un retablo donde dar cobijo a sus imágenes. Para ello pensaron en una rica y ostentosa decoración de mármoles con predominio de blancos y negros, que fuese digno marco donde exponer a la veneración pública la imagen del Santo Cristo de Aguiniga y de la Virgen del Socorro en los lugares preferentes, y la de los cuatro abogados de la Señoría en las hornacinas de los intercolumnios ${ }^{3}$.

La inscripción nos dice el resto: "ESTA CAPILLA ES PROPIA DE LA / NACIÓN GINOVESA. REEDIFICOSE / CON ESTE RETABLO DE IASPES / Y ALABASTROS AÑO DE |67|".

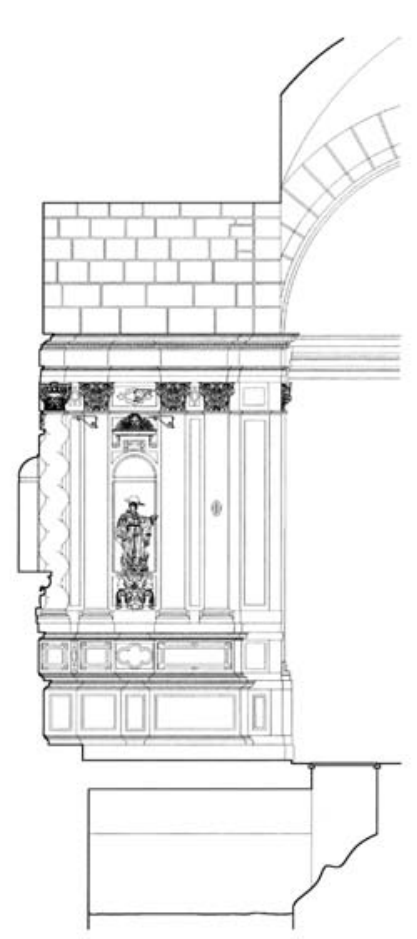




\section{Atribuciones}

Del autor/res de la obra no hay noticias directas, pero los acontecimientos posteriores apuntan la atribución a los hermanos Andrea y José Antonio Andreoli, naturales de Carrara, que trabajaron en Cádiz en la segunda mitad del siglo XVII.

En primer lugar por la elección de los italianos para la construcción de una obra de la importancia de la Portada lateral de la Catedral Vieja. En el acta capitular del 28 de septiembre de 167I hay constancia de que la portada se tenía ajustada con el nuevo maestro genovés, advirtiendo de "la buena ocasión que era para la proyectada portada estar aquí el maestro que iba a Génova"4.

La explicación es la siguiente. El cabildo, molesto de que en el primer templo una corporación extranjera tuviese, a su modo de ver, un altar superior al que hizo para ellos Saavedra, encarga a Andreoli una portada de la que se espera si no mayor sí el mismo éxito que el retablo genovés.

El contrato se formaliza en sucesivos años y las instrucciones dadas hablan por si solas -la forma y calidad de las esculturas debe ser similar a las del retablo de la capilla genovesa, así como la hechura de la portada ha de ser también salomónica-. El recuerdo de la obra ejecutada para los genoveses está, por su cercanía física y cronológica, muy presente 5 .

De los hermanos Andreoli hay escasas noticias. Nunca tuvieron residencia fija en Cádiz, apareciendo sólo durante pequeños periodos de tiempo suficientes para cerrar los contratos. No se encargaban de realizar los montajes, limitándose a confeccionar las piezas en Italia que traían en barco desde Génova. Una vez descargadas en la bahía, otorgaban la carta de pago de haber entregado la obra y cobraban la totalidad del dinero. En su ausencia, su colaborador Simón de Rivas, milanés afincado en Cádiz con el que compartían un taller en el Baluarte de Santa Cruz, en un sitio llamado "Los Barrancos del Carbón", se encargaba de cerrar diversos tratos. Allí almacenaban las obras hasta su completa instalación, y allí iban los clientes a adquirir piezas o hacer encargos.

Una última circunstancia viene a afianzar la atribución a los hermanos italianos. El hallazgo del contrato del Retablo mayor de la Iglesia de Santo Domingo de Cádiz, de hechura idéntica al genovés, y que ejecutaron los hermanos Andreoli entre 1683 y 1691.

El mencionado contrato ha permitido además, determinar el verdadero alcance de las actuaciones de los italianos en Cádiz, quedando constancia de que su trabajo se limitaba a la materialización en mármol de los encargos que les encomendaban, jamás del diseño. Ello justifica el título con el que se hacían llamar "maestros en arquitectura de mármoles" o "maestros en obras de jaspes", nunca arquitectos o escultores 6 .
Del mismo modo, la portada lateral de la catedral ya estaba proyectada cuando se solicitó su ejecución a Andreoli, teniendo conocimiento de que la traza corrió a cargo del ensamblador Juan González de Herrera ${ }^{7}$.

En cuanto al diseño del retablo ligur, Sancho de Sopranis considera que en la distribución del conjunto ciertos elementos decorativos recuerdan remotamente, y en el retablo dominicano mucho más, a algunas obras de Francisco Dionisio Rivas, salvando distancias por tratarse de retablos en madera 8 .

Por el contrario, Fray Vicente Díaz considera que el retablo de Santo Domingo debió diseñarlo el propio Juan González de Herrera, por las semejanzas que presenta con la desaparecida portada lateral de la catedral, dibujada por el mismo Díaz según la descripción de Jerónimo de Concepción.

Para Alonso de la Sierra esta práctica era frecuente en Cádiz durante las últimas décadas del siglo XVII. A falta de maestros marmolistas en la ciudad, se contrataba a especialistas llegados de Italia que ejecutaban los encargos que previamente habían diseñado los maestros locales.

Creemos que en el Retablo de los Genoveses también se llevó a cabo esta práctica. Primero por las semejanzas que presenta su único cuerpo con el primero del retablo dominicano, con la misma configuración de sus calles, y en segundo lugar, por el recuadro del crucificado localizado en la calle central. Esta solución fue ideada por maestros locales para integrar estas imágenes en los retablos. Sabemos que se había experimentado antes en el desaparecido retablo de la vecina capilla de los vizcaínos, siendo probable que se tomara como modelo en el genovés?

Junto al Retablo de los Genoveses fueron encargadas cuatro esculturas de mármol para decorar sus hornacinas: San Jorge, San Juan Bautista, San Lorenzo y San Bernardo. Están atribuidas al carrarés Esteban Frugone, escultor del que hay constancia que colaboró en otras obras significativas de los Andreoli en Cádiz, tal y como consta en las inscripciones localizadas en varias esculturas de los mencionados Retablo mayor de Santo Domingo y Portada lateral de la Catedral Vieja 10

Sobre este artista no hay noticias de su presencia en Cádiz. Se cree que nunca estuvo en la ciudad y que sus obras eran traídas desde Génova por los hermanos Andreoli junto con las piezas labradas para la portada. Pensamos que debió de ocurrir otro tanto con las esculturas del retablo dominicano.

Por el contrario, la falta de inscripciones en las esculturas del retablo genovés junto con las diferencias estilísticas que expondremos a continuación, han llevado a descartar la atribución de la estatuaria a este escultor.

Primero porque el estilo y ejecución de estas imágenes difiere con respecto a las que se encontraban en 
0
$上$
$z$
$\Sigma$
5
0
0
0

5. Retablo mayor de la iglesia de Santo Domingo en Cádiz

6. Reconstrucción de la antigua Portada lateral de la Catedral Vieja según Fray Vicente Díaz
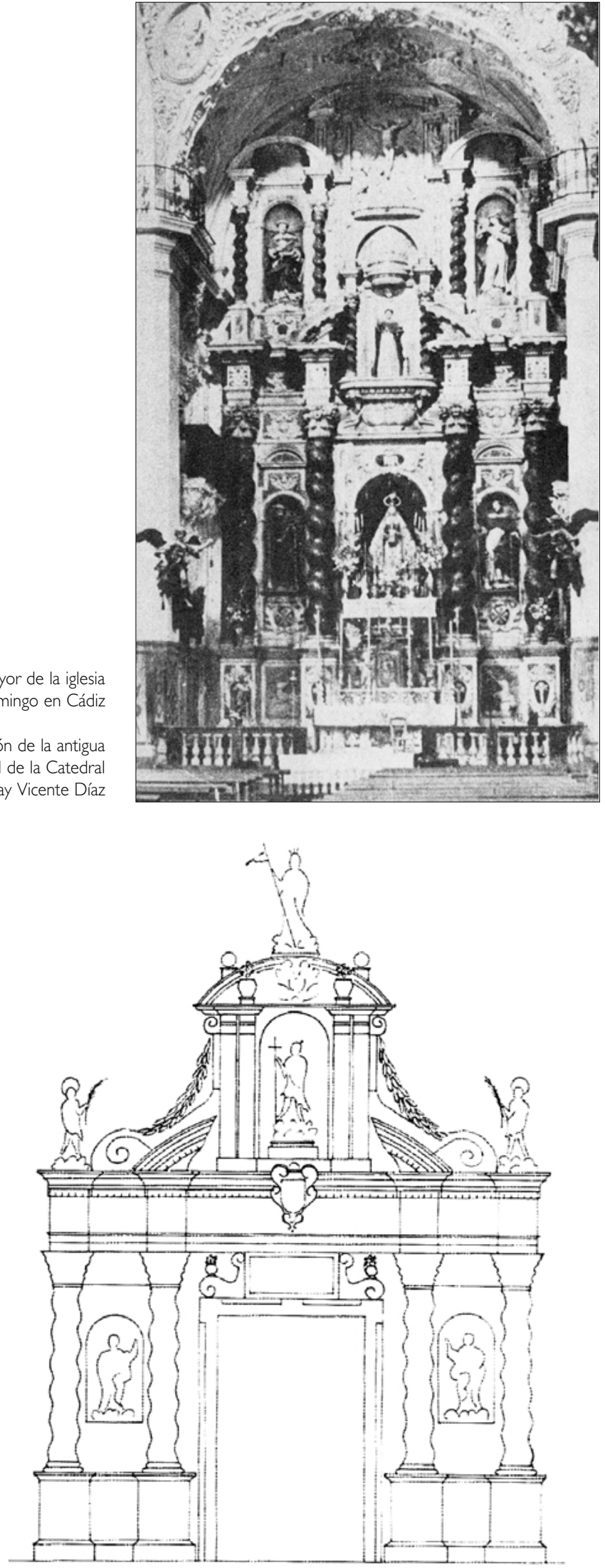

la portada, además de que fueron ejecutadas en fechas muy próximas siendo las de la portada de 1673 y las del retablo de un par de años antes, resultando imposible atribuirlas a una misma persona.
En segundo lugar porque dentro de las esculturas del retablo que nos ocupa, se aprecia falta de unidad, conformando dos grupos de estilo, composición y características diferentes. Por una parte, las de San Bernardo y San Lorenzo están concebidas mediante formas y actitudes cerradas con predominio de la frontalidad, frente a las de San Jorge y San Juan Bautista, de gestos más espontáneos y composiciones más abiertas.

Que los Andreoli contraten a dos artistas para ejecutar la estatuaria de una obra no es excepcional. En el aludido Retablo de Santo Domingo hay constancia epigráfica de que además de Frugone intervino otro escultor llamado Jacopo Antonio Ponzanelli "I.

Es probable que Andrea y José Antonio Andreoli poseyeran un taller en Génova donde almacenaban esculturas de distintos artistas. La falta de inscripciones en las imágenes obedece a ciertos ajustes que se realizaban para acoplarlas a sus respectivos lugares mediante el recorte de peanas, y en menos ocasiones, suplementándolas con piezas para realzarlas y casarlas con los lugares asignados 12 .

Tal vez sea este el motivo de que no se hallen las inscripciones en las esculturas del retablo de la nación genovesa, por lo que resulta imposible formular una atribución coherente.

\section{Descripción}

El Retablo de los Genoveses se localiza en la cabecera de la nave del evangelio de la Catedral Vieja de Cádiz. Ocupa todo el frente y los dos laterales de la capilla y consta de un banco, un único cuerpo configurado a modo de trí́tico -compuesto de tres calles en el plano frontal y dos en los laterales-, y un ático que remata todo el frontal.

Por su ubicación en el templo se denomina retablo de crucero. Está realizado en mármoles de Carrara, jaspes y calizas, siguiendo la línea de los retablos italianos, y consta de una estructura muy básica, consistente en una planta rectilínea poligonal a partir de la cual se articula todo el retablo.

Por sus características responde al estilo barroco en el uso de la columna salomónica como soporte que se impone en la segunda mitad del XVII y el empleo del orden compuesto en los capiteles. Se observan otros recursos propios de la época, como el resalte de la calle central mediante el uso de columnas pareadas, la presencia del frontón partido o el empleo de la línea quebrada a lo largo de todo el entablamento.

Asimismo, durante este periodo se lleva a cabo una simplificación estructural en los retablos, reduciéndose considerablemente el número de cuerpos y calles. Ello se traduce en una disminución de los motivos decorativos que terminan replegándose a áreas concretas. En el retablo que nos ocupa, la decoración se 
localiza en el banco, los alrededores de las hornacinas y en el fondo del ático.

Otro aspecto decorativo a destacar es la constante búsqueda de contrastes mediante el uso de mármoles blancos y negros. Consiste en seleccionar el mismo color en los elementos arquitectónicos repetidos, pero evitando que coincida en aquellas piezas que se presentan correlativas. De esta manera se crean contrastes entre las zonas resaltadas y las más retrasadas -soportes en mármol negro separando las calles en blanco- y en las superposiciones de elementos, tanto en sentido vertical -fustes oscuros entre basas y capiteles claros-, como en horizontal -calles en mármol blanco mientras el interior de las hornacinas es de caliza negra-, creando un juego de alternancias en todo el retablo e identificando cada elemento dentro del conjunto.

\section{Procedamos a su descripción formal}

En el banco, adosado al sotabanco, destaca la mesa de altar sobre un doble peldaño. Está profusamente decorada mediante ángeles atlantes de medio cuerpo sobre pedestales, coronados por volutas que alternan con cenefas dispuestas en vertical, situándose en el centro el anagrama de Cristo. El resto del sotabanco lo decoran paralelepípedos rectángulos de distintas dimensiones y disposición, vertical u horizontal, en serpentinita con el borde de caliza roja.

Continuamos con la predela, de disposición similar, pero con un repertorio decorativo basado en la alternancia de paralelepípedos rectángulos en caliza roja remarcados por aristas blancas y negras y círculos negros en las esquinas, con otros decorados con figuras tetralobuladas en falsa piedra de ágata e inscritos en un rectángulo de mármol negro. Sobre la mesa de altar se sitúa el sagrario, acoplado por sus laterales a una triple grada adornada con motivos florales y rombos alternos.

Sobre el conjunto del banco se sitúa el único cuerpo del retablo. Está conformado por calles frontales y laterales delimitadas por columnas salomónicas y pilastras respectivamente. Ambos soportes están rematados por capiteles compuestos de ovas y hojas de acanto con volutas, y asentados sobre basas áticas sobre un plinto.

Remata el cuerpo un entablamento quebrado que configura los planos laterales mediante niveles rehundidos y resaltados alternos, mientras en el plano frontal se adelanta la calle central, a partir de la cual van retrocediendo las calles y entrecalles/soportes contiguas.

Los planos laterales presentan una única calle en el centro, flanqueada por un doble soporte separado por medio de un alargado paralelepípedo coronado por un rombo inscrito en un rectángulo. Mientras la entrecalle/soporte que abre los laterales se compone de dos pilastras, la que lo cierra presenta sólo una junto a una columna salomónica. Esta última se sitúa en la esquina y une los planos laterales con el frontal, pero sólo actúa como soporte del entablamento frontal.

Las calles se conforman de una hornacina semicilíndrica coronada por cuarto de esfera y decorada mediante un tarjetón, un relieve con la cabeza alada de un querubín y un rombo dispuesto en horizontal con lóbulos circulares en sus vértices y aristas. En la base de la hornacina se localiza una repisa prismática que descansa sobre una ménsula decorada con una exagerada moldura de perfil de volutas y paños colgantes.

En el plano frontal las calles se presentan idénticas a excepción de la central, más ancha y alta que las laterales y resaltada mediante columnas salomónicas pareadas. Tiene una configuración distinta. La mitad inferior la ocupa una hornacina similar a las que se han descrito, aunque más baja y ancha y profusamente decorada. Aparece coronada por un frontón curvo con volutas en las esquinas y cuyas enjutas se adornan con relieves de cabezas aladas de querubines. Toda la decoración está remarcada por una moldura sostenida por columnillas de fuste recto y liso con capiteles compuestos sobre basas áticas realzadas mediante dados. Decoran los huecos hasta las jambas rombos y óvalos alternos, que continúan en el frontal de la base alternando también con motivos florales y círculos. En su interior se asienta la imagen escultórica en mármol policromado y dorado de la Virgen del Rosario de los Milagros.

Esta mitad contrasta con la parte superior de la calle central, despojada de adornos y que tan sólo presenta un recuadro estucado en negro con la forma del crucificado que acoge sobre dos cruces planas superpuestas.

Toda esta calle se encuentra delimitada por una doble moldura, que en la parte superior rompe el entablamento quebrado y alcanza al ático, asentado en la cornisa sobre un friso corrido rematado con dentículos.

Preside el ático un frontón calado que muestra la base rota por la presión del recuadro del crucificado, rozando los dentículos que adornan la cornisa. Bajo el ápice aparece el relieve con la cabeza alada de un querubín, de factura similar a los anteriores.

Sobre el frontón se asientan las esculturas del Padre Eterno flanqueado por dos ángeles. Están realizadas en mármol blanco y presentan los rostros y la barba (del Padre) policromados. Al fondo del ático se dispone una decoración radial, compuesta de motivos florales que se interrumpe en el centro, mediante un plano oscuro que resalta la figura central.

Finalmente, cierran la capilla por ambos lados gigantes pilastras rectas con acanaladuras en falsa piedra de ágata. 
0
$上$
$z$
$\Sigma$
$\Sigma$
0
0
0
0

7 y 8. San Lorenzo y San Bernardo. (Procedentes del Inventario de Bienes Muebles de la Iglesia Católica. Diócesis de Cádiz).
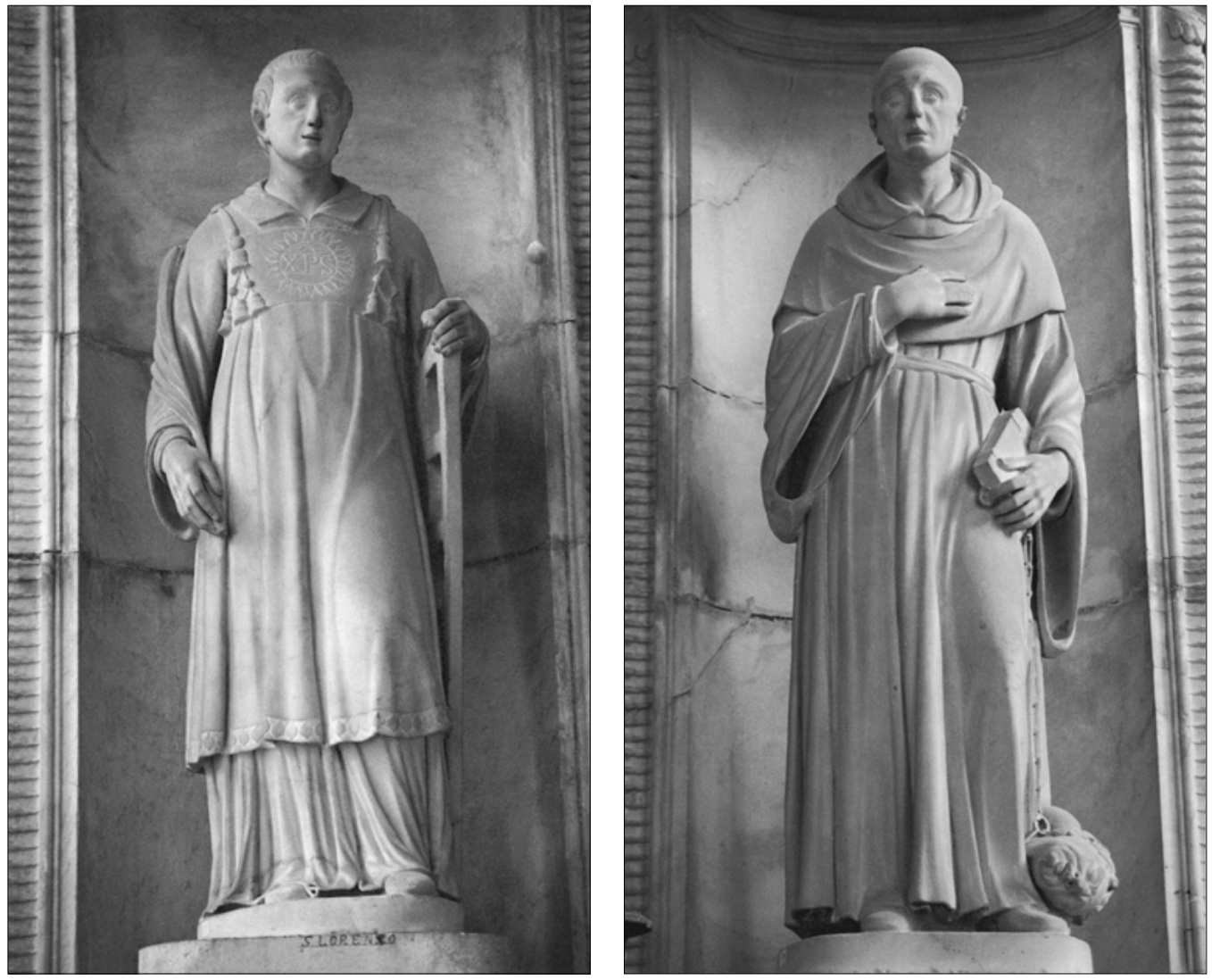

\section{Cambios en el programa iconográfico}

Parte de la escultura que compone el retablo en la actualidad, está desvinculada de su iconografía original.

La Catedral Vieja, junto con otras iglesias de su entorno, padeció el expolio de sus bienes con objeto de decorar las capillas y portadas de la Catedral Nueva de Cádiz, habida cuenta de la falta de recursos económicos con que afrontarlas.

Entre todas las obras que se requisaron se encontraban las cuatro esculturas de mármol que ocupaban las hornacinas laterales del único cuerpo del Retablo de los Genoveses.

Fueron enviadas a la Catedral Nueva en la segunda mitad del siglo XVIII. Las imágenes de San Jorge y San Juan Bautista al altar de la capilla de San José, y las de San Lorenzo y San Bernardo a la capilla del Santo Ángel de la Guarda. Ambas capillas se localizan en la girola de la catedral.

Con motivo de este traslado sufrieron una intervención consistente en la eliminación casi total de la policromía que presentaban, siguiendo las pautas marcadas por el Neoclasicismo. Originariamente eran monócromas, pero al entusiasmo del retablo se unió una fuerte crítica por la frialdad de las imágenes que no casaban con los gustos locales "aplicándoseles una ligera policromía consistente en el dorado de los cabellos y suaves encarnaduras en los rostros". Sin embargo, hay constancia de que esta policromía fue mucho mas extensa, conservando resto que atestiguan que estuvieron totalmente policromadas. El resto de las esculturas originales del retablo conserva su antigua

En su ubicación original se localizan actualmente cuatro esculturas en madera policromada procedentes de antiguos retablos desaparecidos de la Catedral Vieja. Conocemos la procedencia de la Virgen y el San Juan Evangelista, ubicados en las hornacinas laterales de las calles frontales, que forman parte del Calvario que adornaba antiguamente la vecina capilla de los vizcaínos.

En los planos laterales se localizan dos santos identificados como San Antonio de Padua y San Juan de Prado, que debieron pertenecer a un mismo retablo del que se desconoce su situación en la catedral, y que rendía culto a la orden de San Francisco.

Por otra parte, el crucificado original que presidía el retablo fue reemplazado en la década de los sesenta por el Cristo de la Espina, también procedente de la capilla vizcaína. Es probable que, tras desaparecer el retablo de los vizcaínos y quedar sin resguardo las imágenes del Calvario, se decidiera colocarlas en las hornacinas vacantes del retablo genovés. Para no desmembrar el conjunto, se determinó reemplazar el crucificado original y colocar en su lugar el de los vizcaínos.

Creemos que el crucificado original, el Cristo de Aguiniga, fue enviado a la capilla de los Obispos sipolicromía aunque muy deteriorada. 
tuada en la cripta de la Catedral Nueva. Había sido donado el 10 de diciembre de 1600 por el rico comerciante gaditano afincado en Nueva España, Clemente de Aguiniga, que lo regaló durante las restauraciones llevadas a cabo en la Catedral Vieja con motivo del saqueo inglés. Posteriormente, el 7 de mayo de $|65|$, el cabildo lo cedió a la nación genovesa definitivamente, sustituyendo la antigua cruz que adornaba la capilla ligur.

Se trata de un Cristo de caña realizado en pasta de médula de maíz y policromado. Representa a un crucificado muerto de tres clavos con la cabeza caída hacia la derecha y el sudario atado al mismo lado. La imagen que le reemplaza es de iconografía similar.

Con respecto a la patrona de la capilla, la Virgen del Socorro, no tenemos suficientes noticias. Debió reemplazar a la imagen gótica de Santa María, ubicada en el altar de la capilla desde su origen en el siglo $\mathrm{XV}$, para desaparecer en el ataque inglés de 1596. Hay noticias de ella anteriores a 1651, año en el que se proyecta el retablo "para dar cobijo al crucificado y a la Virgen del Socorro". Creemos que reemplazó a la imagen medieval a comienzos del siglo XVII, cuando se procedió a adecentar las capillas de la catedral a petición del cabildo.

Tampoco sabemos si la imagen original es la actual. Esta Virgen, entronizada como una maestá, sostiene en su izquierda al Niño que sujeta con ambas manos una filacteria. La imagen no se corresponde iconográficamente con la Virgen del Rosario de los Milagros con la que se identifica en la actualidad, al no acompañarle ni encontrar indicios de su atributo, el rosario. Tampoco es la Virgen del Socorro, ya que suele representarse de forma totalmente opuesta y con una actitud menos dulcificada. Los atributos localizados junto a sus pies, dos llaves cruzadas sobre una corona real, hacen alusión a la Iglesia de San Pedro en el Vaticano, coincidiendo su iconografía con la Virgen de la Santa Sede.

La documentación referente al traslado de las imágenes de los santos a la Catedral Nueva no menciona la ubicación individual de estas esculturas antes de su expolio, por lo que debe deducirse a partir de otras consideraciones.

Tomando como referencia los aspectos iconológicos e históricos expuestos en el presente estudio, y habiendo constatado que las cuatro imágenes conforman dos parejas formalmente diferenciadas, concluimos que el emparejamiento actual es producto de su planteamiento original, proponiendo el siguiente reparto. La pareja formada por San Jorge y San Juan Bautista se ubicaría en el plano frontal del retablo. A San Jorge, como patrón de Génova y de la capilla de los genoveses, le corresponderá el lado del evangelio, asignándose a San Juan Bautista el lado de la epístola, lugar dónde se le ubica con más asiduidad.

En las calles situadas en los planos laterales se localizarían San Lorenzo, como titular de la catedral, en el lado del evangelio, mientras San Bernardo lo hará en la hornacina que resta en el lado de la epístola.

Este conjunto representan a los cuatro abogados de la señoría defensores de la república de Génova y son parte inseparable de la iconografía original del Retablo de los Genoveses.

Finalizamos con las esculturas ancladas que presiden el retablo, el Padre Eterno y los dos ángeles, como las únicas imágenes que han permanecido unidas al mismo desde su constitución.

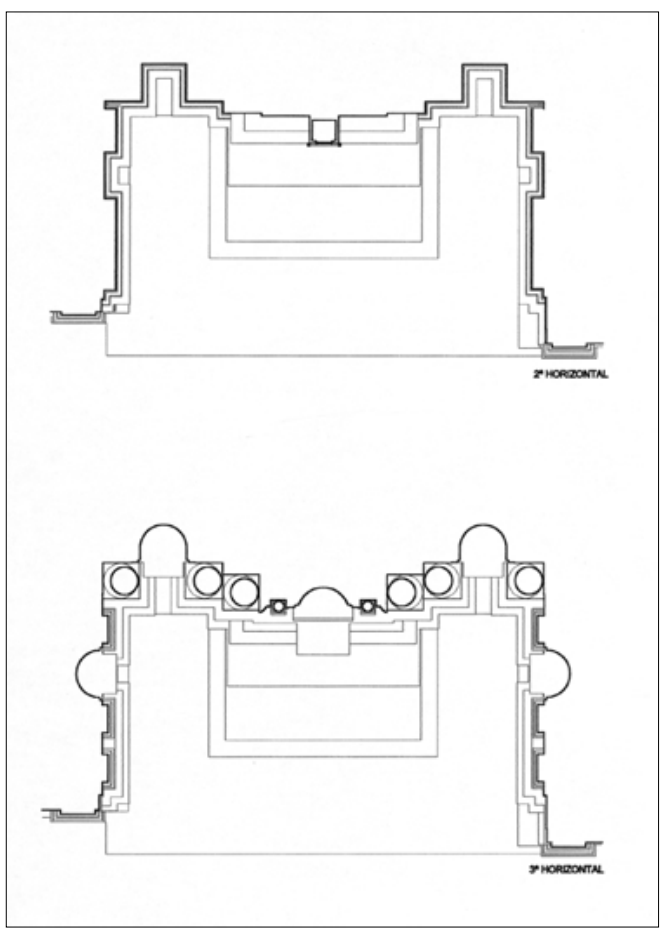

9. Plantas de la capilla cortando por la alacena del Sagrario y por las hornacinas de las calles laterales, (estudio MLM\&PRP)

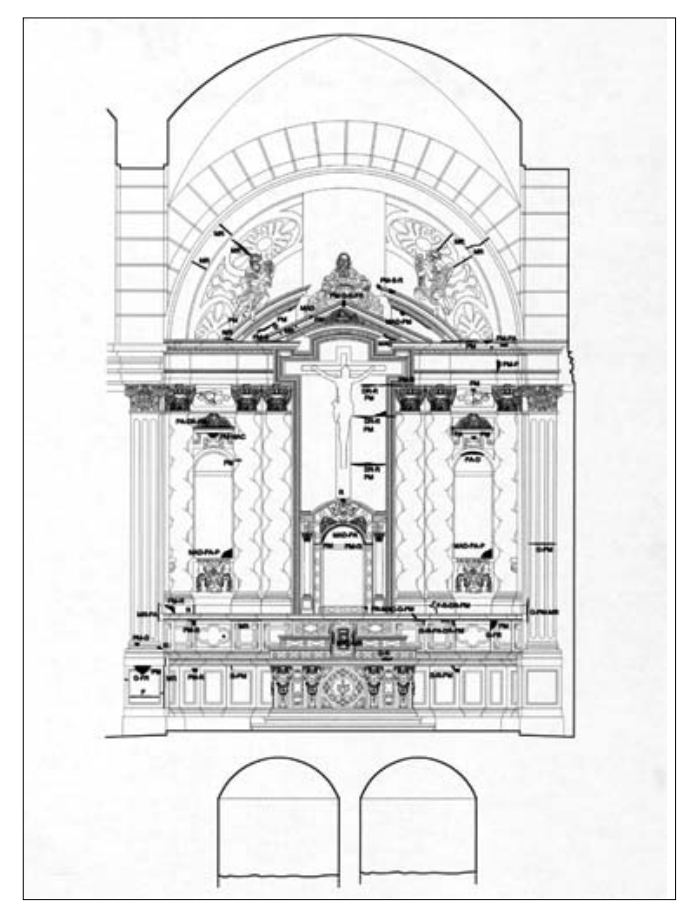

10. Muestra de la representación de alteraciones sobre el frontal del retablo, (estudio MLM\&PRP) 


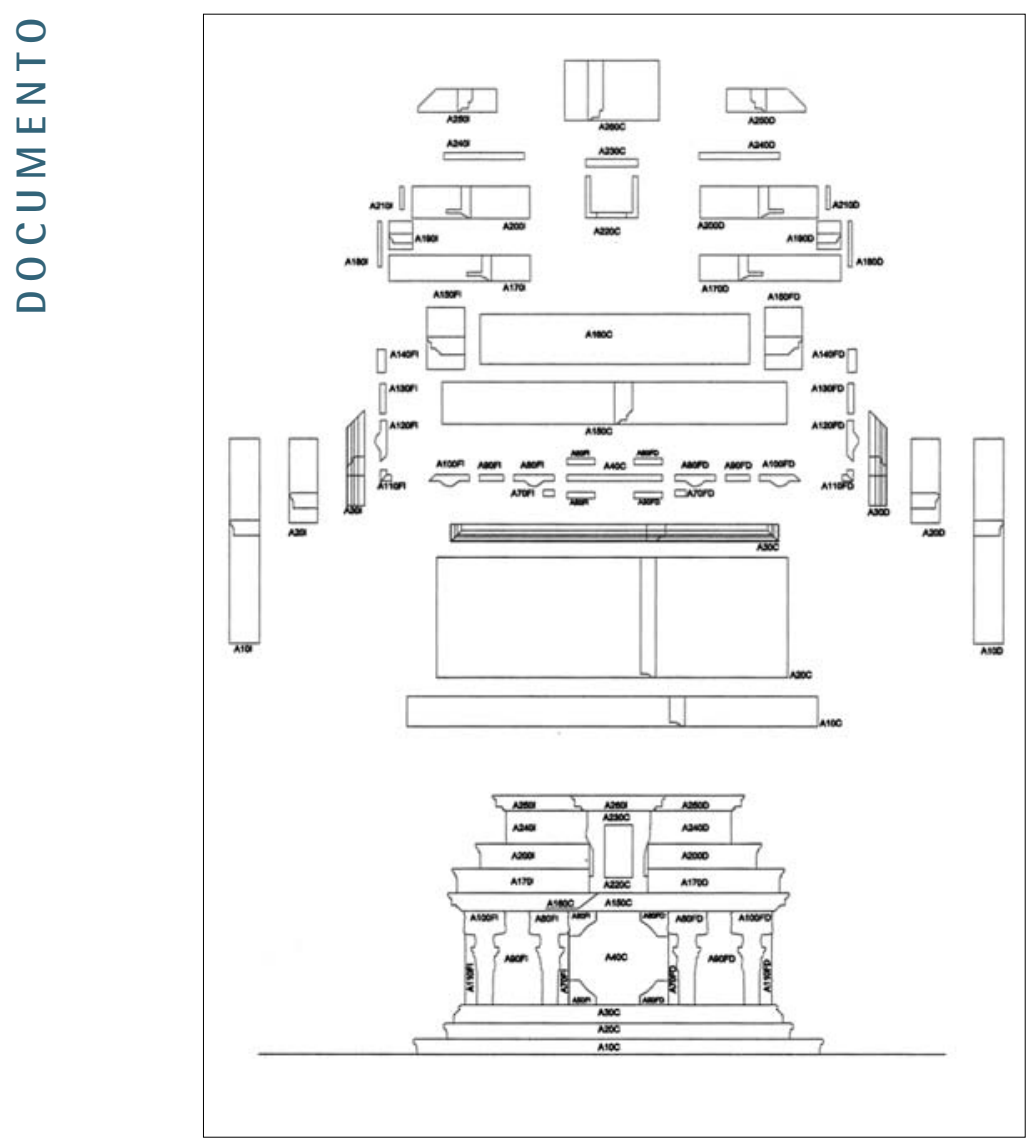

I I. Ejemplo de representación del despiece aplicado al altar y sus gradas, (estudio MLM\&PRP)

12. Cubiertas de la Catedra Vieja, mostrando su proximidad al mar y el deterioro de sus azulejos, (estudio MLM\&PRP)

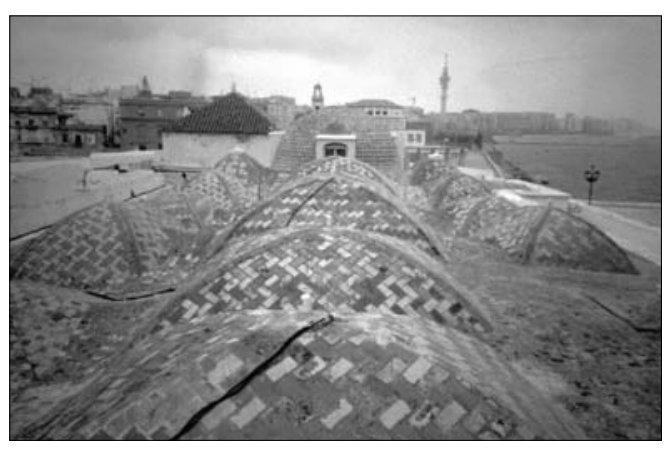

\section{Estado de conservación de la capilla y} del retablo

Complementaremos la definición y la patología materiales, así como la aproximación a sus causas, descritas en el informe geológico, con la mención de ciertas irregularidades, disimetrías y faltas de coincidencias entre piezas, indicios evidentes de correcciones en la puesta en obra del conjunto, probablemente para compensar defectos de fabricación o para el aprovechamiento de piezas equivocadas suministradas desde el taller de origen ${ }^{13}$.

El ejemplo más notable de este tipo de actuaciones es, sin duda, el de la columna salomónica del extremo izquierdo del lienzo frontal, cuyo fuste "gira en sentido contrario al que le corresponde", y debería haber sido devuelta y sustituida por otra. Junto a este podríamos citar, entre otros, las correcciones de los frontones, especialmente en la cúspide del recto, para modificar su ángulo de apertura, haciendo caso omiso de la inclinación de los dentículos, y otros muchos de rellenos de juntas de anchura excesiva, posteriormente estucados imitando la policromía de las piedras naturales que sustituían.

Es imposible por ahora discernir cuantas de estas operaciones corresponden a la construcción original y cuantas a momentos posteriores, salvo las apuntadas en el citado informe, basadas en la composición de los morteros, especialmente en la presencia de Litopón.

\section{Estudio climático de la capilla}

Contamos con tres registros gráficos continuos que abarcan desde el 24 de Abril hasta el 14 de Junio de 1995, tomados respectivamente a nivel del suelo, a 4 y $7 \mathrm{~m}$ de altura, complementados por mediciones discontinuas del mismo periodo tomadas a cada metro de altura desde 0 hasta 10.

Asimismo, contamos con registro continuo desde el I de Mayo hasta el 30 de Septiembre de 1999, a las mismas tres alturas.

De los resultados de dichos estudios, se deduce que las peores combinaciones de temperatura seca-humedad relativa, por resultar más próximas a las de saturación del aire, se dieron en primavera y otoño, aunque las condiciones de pleno verano no son mucho mejores.

\section{Diagnóstico preliminar}

Como se recoge en el informe geológico, el deterioro de las piedras y elementos férricos de anclaje de las mismas al soporte mural se debe a la gran humedad ambiente del lugar, unida a la existencia de cloruros, y a las combustiones de velas y otros artilugios relacionados con el culto, así como por la afluencia de fieles desde su fundación hasta hace poco (la capilla lleva sin uso desde hace cuatro años).

Dicha humedad interna produce, aún hoy, condensaciones visibles en el suelo y sobre los paramentos del retablo, incluso sobre el polvo depositado en el mismo en gran abundancia.

Esto se puede ver propiciado, en nuestra opinión, por la humedad de la masa mural, debida a filtraciones de agua de lluvia por puntos débiles, como el ventanal cegado en la zona del ático del retablo, por los rincones de cubierta cercanos a la embocadura de los bajantes y, en alguna medida también por ascensión del agua procedente del terreno, especialmente de las áreas vecinas más elevadas.

El agua que eventualmente llegue a la masa del suelo y de los muros, especialmente al muro exterior, ve restringida su evaporación por la presencia de un enfoscado de baja permeabilidad al vapor, en su cara 
externa, y a los aplacados de mármoles y calizas del retablo por la interna, con lo que su permanencia y difusión en la fábrica aumentan, afectando así a los morteros de unión y disminuyendo su capacidad de aislamiento térmico, e incluso su resistencia mecánica.

Este efecto de pared relativamente fría, propiciado además por la orientación de la cara externa del muro hacia el Nordeste, hace bajar la temperatura interna y superficial de los aplacados del retablo por debajo del punto de rocío, con más frecuencia, y en épocas de más calor de lo que parece intuitivamente, y por tanto de más humedad absoluta en el aire de Cádiz.

Los procesos de oxidación de las garras y anclajes, originan la fisuración y las roturas locales de las masas de piedra y los aplacados. La consecuente falta de sujeción lateral por pérdida de sección de dichos herrajes, aumentada por los ataques de los cloruros del aire y los sulfatos de algunos morteros de yeso o de productos de alteración en forma de costras, dan lugar a inestabilidades y sobretensiones, que provocan la aparición de fisuraciones, grietas, roturas, fragmentación -originando la caída y pérdida de partes de las tallas-, etc., junto con la disminución de estabilidad de las esculturas superiores.

Se observan además alteraciones relativamente puntuales (y controvertidas) tales como la ejecución y posterior eliminación voluntaria de la policromía añadida a las esculturas y otras no significativas para la generalidad en que nos estamos moviendo.

El diagnóstico es pues de decohesión gradual y creciente de los materiales rocosos del retablo, sobre todo los expuestos a temperaturas por debajo del punto de rocío, especialmente rincones y partes altas; y de rotura, desplazamiento y ruina progresiva de sus elementos constituyentes por falta de adherencia y anclaje al soporte mural.

En cuanto a la escultura localizada en el Retablo de los Genoveses, por su disparidad cabe clasificarla en dos grupos en base a su composición material. Por una parte estarán las esculturas pétreas -Padre Eterno, ángeles laterales, San Jorge, San Juan Bautista, San Lorenzo y San Bernardo- y por otro, el Crucificado de Aguiniga, que como antes se indicó es de pasta de médula de caña de maíz.

Las primeras, realizadas básicamente en mármol blanco de Carrara, presentan un estado de conservación medio, si se excluyen la gruesa capa de polvo de diversa procedencia que las cubre, la eliminación casi completa de la policromía -cuyos restos aparecen oscurecidos por costras de suciedad- con la inevitable secuela de cierta cantidad de arañazos, y alguna intervención de conservación puntual para rellenar una grieta, caso de la imagen de San Juan Bautista, así como diversas mutilaciones y desapariciones de miembros (algún ala, dedos de las manos más expuestas, etc.), probablemente debidas a manipulaciones poco cuidadosas.
No se aprecian a simple vista alteraciones de importancia en la piedra, a pesar del alto grado de humedad de su entorno actual.

Respecto al crucificado, para cuyo "cobijo" y el de la Virgen del Socorro se edificó el retablo que nos ocu$\mathrm{pa}$, las circunstancias son muy diferentes, pues presenta graves deterioros, tanto en el soporte como en la policromía y las capas de preparación de la misma.

Los más graves son una grieta que lo recorre desde la cabeza hasta el muslo derecho, además de otras dos que cruzan la espalda, así como varias fisuras coincidentes con los ensambles y con la ubicación de los clavos, debidas a la oxidación parcial de los mismos. Algunos dedos de las manos están mutilados y se observan orificios debidos a la presencia de xilófagos.

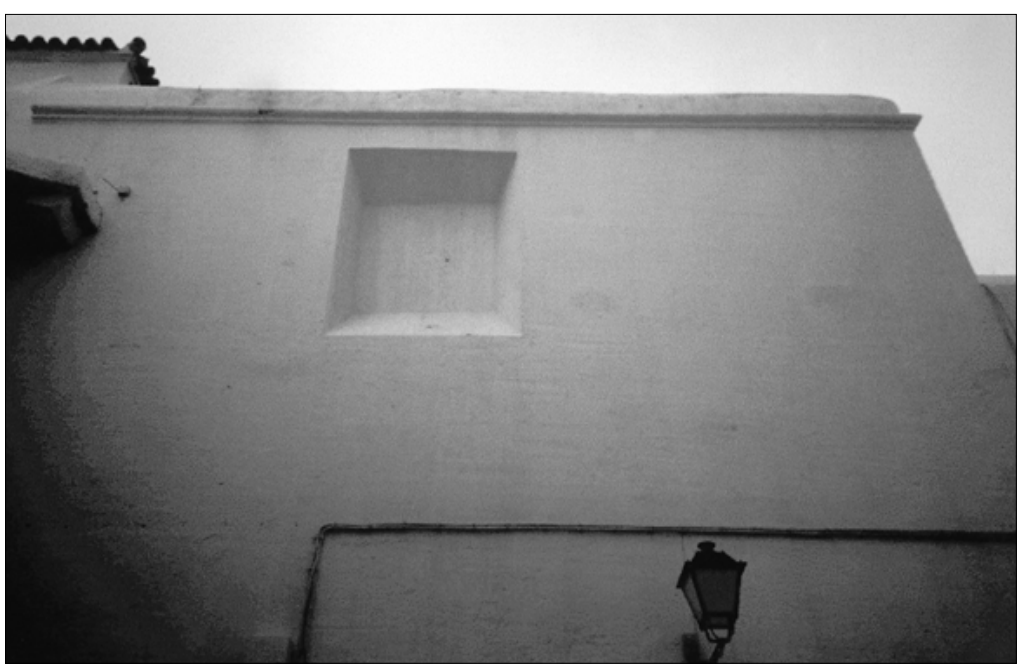

3. Paramento exterior del muro soporte del frontal del

La policromía, presenta diversas áreas craqueladas en el tórax y el cuello, así como levantamientos en los bordes y lagunas correspondientes a las zonas de fractura del soporte, estando fuertemente oscurecida por acumulación de residuos procedentes de los humos, sobre todo por debajo de los brazos.

Es posible que muchos de los daños descritos se hayan ocasionado o agravado a causa de la gran humedad de la cripta donde se ubica, con especial incidencia en el ablandamiento del soporte y la consiguiente pérdida de la policromía.

\section{Acciones de consolidación, restauración y conservación preventiva que proponemos}

Comenzaremos por las que nos parecen mas urgentes:

- Frenar la ruina de los elementos más inestables del conjunto.

- Retirar las esculturas de madera procedentes de otros retablos. 
0
$上$
$z$
$\Sigma$
$\vdots$
0
0
0

14. Detalle del ápice del frontón recto del retablo, en el que se aprecian las cuñas para modificar el ángulo con el que se realizó en taller, (estudio MLM\&PRP)

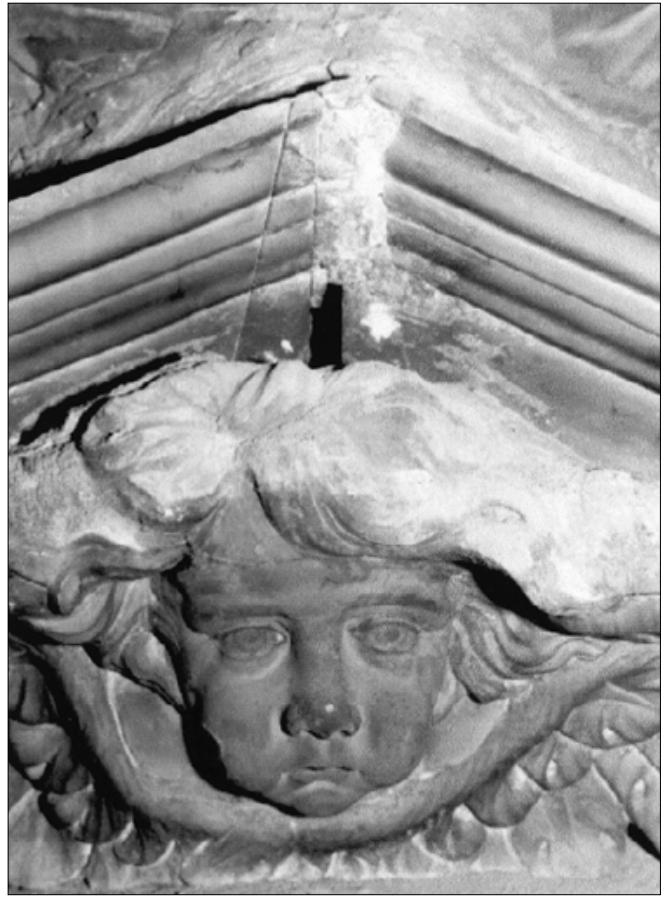

- Acometer la limpieza inicial del mismo, por restauradores especializados, sin perder los fragmentos sueltos ni los detritos de rocas pulverizadas y los restos del ventanal cegado del ático para investigar más a fondo sus revestimientos, realizándose las consolidaciones provisionales necesarias.

- Signar las piezas en general, con el apoyo del despiece ya realizado, que permite interpolaciones y ajustes.

- Continuar la toma de datos climáticos de los espacios y las masas constructivas de la capilla y del exterior, extendiéndolos a la temporada invernal, de forma que sirva de base para optimizar el sistema (pasivo, activo o mixto) de regulación de su temperatura, en función de la humedad relativa presente y de su evolución previsible.

Estas actuaciones que podríamos calificar de urgentes, deben continuarse con una intervención ordinaria que contemple:

- El desmontaje sistemático y completo de las piezas del retablo, y su retirada a taller, dejando marcas seguras e indelebles de su posición en la capilla y en modelo gráfico informático, con referencia a puntos fijos, para permitir el posterior remontaje del mismo.

- Su limpieza y consolidación individual, eliminando materiales de alteración tales como las costras, restos de elementos férricos corroídos, morteros, resinas y materiales de acabado inadecuados, reparando grietas y fisuras y disponiendo grapas, anclajes y refuerzos de acero inoxidable, fibra de vidrio o de carbono.

- Devolución de la cohesión a la piedra hasta donde sea posible e imprescindible, tomando los datos signi- ficativos geométricos, mecánicos, ponderales, cromáticos, etc. y su evolución a lo largo de los procesos arriba indicados, por los medios más adecuados en cada caso, con apoyo del Departamento de Análisis del propio Instituto Andaluz del Patrimonio Histórico.

- La sustitución de las piezas o fragmentos no recuperables por otros de materiales análogos de entre los que estén al alcance en el mercado actual de rocas ornamentales.

- Las pruebas de montaje "en blanco" que aseguren la corrección del remontaje definitivo en la capilla.

En cuanto a las actuaciones en la zona de la propia capilla de los genoveses, mientras se produce la restauración de las piezas en taller, estarían:

- El picado general del revestimiento mural exterior y su sustitución por otro adecuado.

- Las intervenciones sobre las cubiertas, sus desagües, los muros y el suelo de la capilla, necesarias para impedir la entrada de agua en la masa de los mismos, sea por infiltración o por capilaridad, así como facilitar la evacuación de la que contengan mediante desecación o drenaje, según los casos.

- La consolidación estructural de suelos, paredes y masas constructivas de apoyo y anclaje de las piezas del retablo, reforzándolas en caso necesario con elementos puntuales de sostén, que permitan repartir el peso y la sujeción de las mismas, de forma que no se acumule en grandes tramos verticales.

- La extensión de una capa aislante térmica por los paramentos interiores de muros y bajo solería, para paliar o erradicar el efecto de pared fría.

- La instalación de un sistema sencillo de oreo y precaldeo del aire exterior, a partir del ventanal del ático del retablo, que permita también la extracción del aire interno por las mismas vías, en caso necesario.

- La disposición, si es posible, de elementos térmicos radiantes por la espalda del retablo y por el frente, combinados con la propia iluminación a disponer, de modo que se garantice un mantenimiento efectivo de la temperatura de la piedra por encima de la de rocío del aire ambiente en los momentos críticos, a bajo costo energético y de mantenimiento.

- El remontaje del conjunto, la solución de las lagunas, la reintegración de las piezas escultóricas que se ha decidido incorporar, una vez restauradas como más adelante se refiere.

- La puesta en valor y en servicio de la capilla, con difusión pública de los procesos anteriores y control de las variables cuya influencia es determinante para el futuro de su conservación, contando con el compromiso expreso de los responsables directos de su custodia, correcto estado de limpieza, utilización y mantenimiento. 
Para la escultura se propone, en el caso de las imágenes pétreas, un tratamiento de limpieza y consolidación similar al resto de los demás componentes del retablo, con las diferencias que impone la presencia de la policromía en mayor o menor medida y los límites de su singularidad, que imposibilitan cualquier compleción de zonas desaparecidas, debiendo ser tratados en todo caso por restauradores especializados, en los talleres a disponer en la propia iglesia de la Santa Cruz.

Lo mismo cabría decir para los procedentes de la Catedral Nueva, con la adición evidente de los correspondientes transportes, a realizar con las debidas precauciones, en embalajes adecuados.

Por el contrario, el Crucificado de Aguiniga constituye un caso aparte, tanto por su naturaleza material como por su estado de conservación, por lo que proponemos que las intervenciones para su consolidación-restauración se lleven a cabo en las dependencias del Instituto Andaluz del Patrimonio Histórico en su sede de Sevilla. Los traslados precedente y posterior entre Cádiz y Sevilla y su estancia en esta última, se harían con las precauciones debidas para evitar el estrés termohigrométrico de la obra.

Finalmente proponemos que las esculturas no originales del retablo queden descartadas, siendo objeto de una intervención puntual de carácter urgente, al margen del proyecto que se describe en este artículo.

En cualquier caso, el I.A.P.H. emitió un informe preliminar sobre el estado de conservación así como la propuesta de tratamiento de estas esculturas, recomendándose la intervención del Crucificado, la Virgen y San Juan Evangelista, por ser de calidad superior a las dos restantes, antes identificadas.

Asimismo, para el traslado de estas cinco imágenes, del retablo de los genoveses al destino que proponga su propietario -el Obispado de Cádiz-Ceuta- podrá disponerse de los mismos medios empleados en el traslado de las esculturas originales.

Una actuación global como la que proponemos, de llevarse a cabo, garantizaría un aumento razonable de la perdurabilidad del Retablo de la Nación Genovesa, con una clara mejoría de su lectura iconológica y formal, siempre que se cumplan los compromisos para su correcto uso, mantenimiento y conservación preventiva.
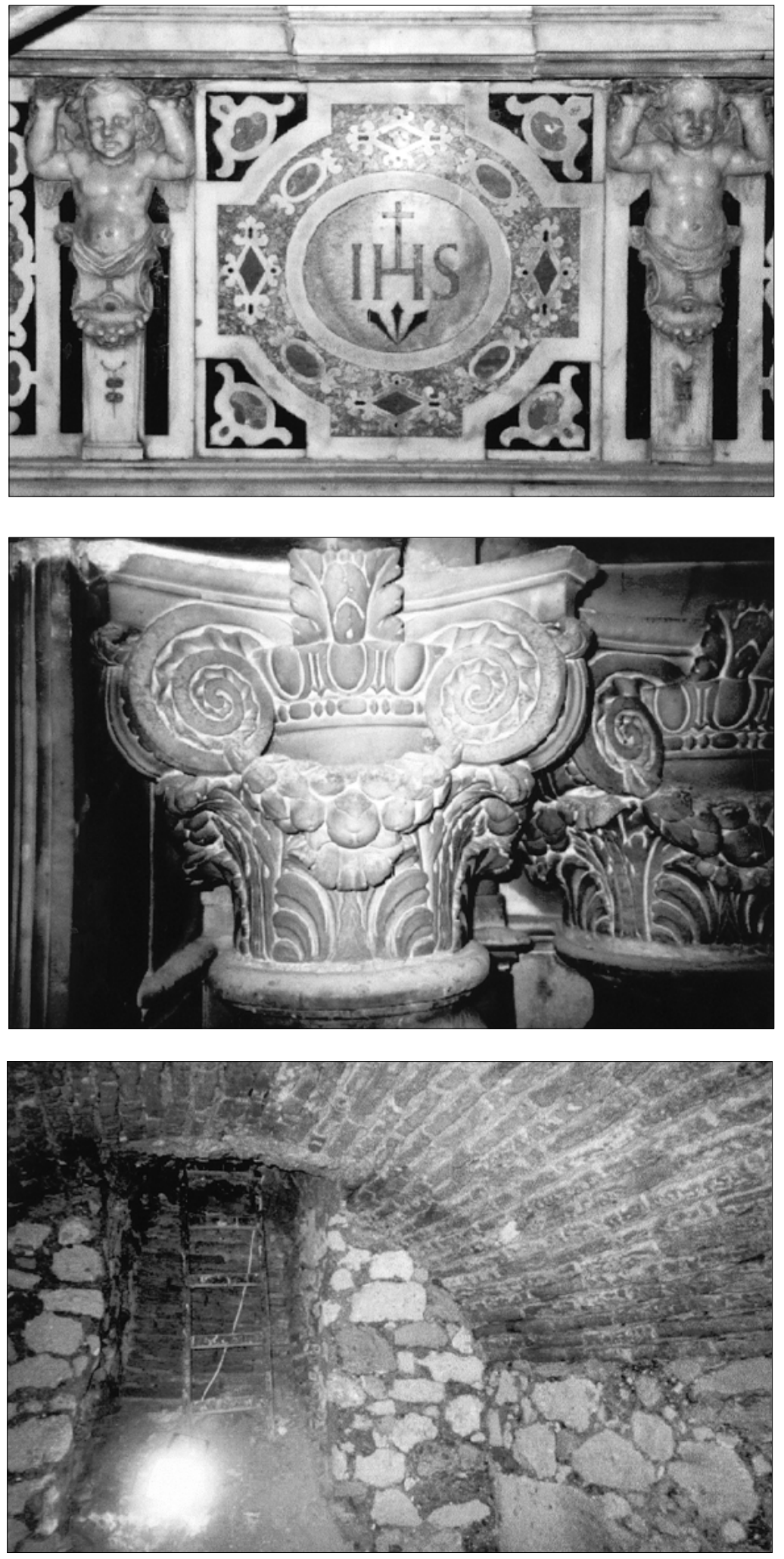

15. Detalle central del frontal del altar, con los ángeles atlantes y el anagrama de Cristo entre taraceas de mármol, (estudio MLM\&PRP)

16. Detalle de los capiteles compuestos de una pareja de columnas salomónicas que flanquea la calle central del retablo y producen el avance relativo de la misma sobre las laterales, (estudio MLM\&PRP)

17. Interior de una de las criptas de enterramiento, (estudio MLM\&PRP) 
Equipo de trabajo. Centro de Intervención del IAPH

Análisis geológico

Jesús Espinosa Gaitán

Geólogo. Departamento de Análisis

Fotografía

José Manuel Santos Madrid

Fotógrafo. Departamento de Análisis

Estudio Climatológico

Raniero Baglioni

Asesor en conservación preventiva. Departamento de Tratamiento
Estudio Arquitectónico

Pedro Rodriguez Pérez

Arquitecto. Jefe del Departamento de Investigación

Estudio Histórico-Artístico

\section{María Campoy Naranjo}

historiadora del Arte. Departamento de Investigación

\section{Bibliografía}

ALONSO DE LA SIERRA FERNÁNDEZ, Juan y Lorenzo: Guía Artística y Monumental de Cádiz. Madrid, 1995.

ALONSO DE LA SIERRA FERNÁNDEZ, Lorenzo: "Mármoles italianos en Cádiz durante el siglo XVIII. Un retablo de Alessandro Aprile". Revista Atrio n 7, año 1995. Págs. 57-66.

CARBAJAL NAVARRO, José y OTERO FERNÁNDEZ, Rafael: "Recomendaciones previas al proyecto de intervención en la Capilla de los Genoveses de la Iglesia de Santa Cruz (antigua catedral), Cádiz". Septiembre de 1994

CONCEPCIÓN, FRAY GERÓNIMO DE: Emporio del Orbe. Cádiz llustrada. Amsterdam, 1690.

DÍAZ, VICENTE: "El Retablo de Santo Domingo en Cádiz". Archivo Dominicano. Salamanca, 1995. Págs. 341-360; "De Fruco a Frugone, o la solución de un enigma". Diario de Cádiz, 9 de diciem- bre de 1990; "Los autores de las imágenes del retablo de Santo Domingo". Diario de Cádiz, 7 de octubre de 1990

RAVINA MARTíN, Manuel: "Mármoles genoveses en Cádiz". Homenaje al Prof. Hernández Díaz. T.I. Sevilla, 1982. Págs. 595-6I5.

SANCHO DE SOPRANIS, Hipólito: "Las naciones extranjeras en Cádiz durante el siglo XVII". Estudios de Historia Social de España. T. IV, volumen 2, 1962. Págs. 66I-700; "La capilla de los nacionales genoveses". La Información del Lunes. Cádiz, 2 y 30 de marzo, 13 de abril y 4 de mayo de 1959

URRUTIA, Javier de: Descripción de la Catedral de Cádiz. Cádiz, 1843.

VORSEVI, S.A. : "Estudio de la Capilla de los Genoveses de la |glesia de Santa Cruz de Cádiz". Septiembre, 1995

NOTAS

I. Sancho de Sopranis, H.: "Las naciones extranjeras en Cádiz durante el siglo XVII". Estudios de Historia Social de España. T. IV, vol. 2. 1962. Pág. 695.

2. Ravina Martín, M.: "Mármoles genoveses en Cádiz". Homenaje al Prof. Hernández Díaz. T. I. Sevilla, 1982. Págs. 596 y 597.

3. Sancho de Sopranis, H.: "La capilla de los nacionales genoveses". La Información del Lunes, 30 de marzo de 1959.

4. Sancho de Sopranis, H.: "Las naciones extranjeras en Cádiz durante el siglo XVII". Estudios de Historia Social de España. T. IV, vol. 2, 1962. Pág. 694

5. Ravina Martín, M.: "Mármoles genoveses en Cádiz". Homenaje al Prof. Hernández Díaz. T. I. Sevilla, 1982. Págs. 599 y 600.

6. Díaz, Vicente: "El retablo de Santo Domingo de Cádiz". Archivo dominicano. Salamanca, 1995. Pág. 350

7. Alonso de la Sierra, L.: "Mármoles italianos en Cádiz durante el siglo XVIII. Un retablo de Alessandro Aprile". Revista Atrio n 7 , año 1995. Pág. 61 .
8. Se refiere concretamente al Retablo Mayor de la Iglesia de Ntra. Sra. de la Consolación (Los Terceros) de Sevilla.

9. Sancho de Sopranis, H.: "Las naciones extranjeras en Cádiz durante el siglo XVII". Estudios de Historia Social de España. T. IV, vol. 2, 1962. Pág. 719

10. La imagen de Santa Catalina en el retablo dominicano consta de la inscripción "STEPHANUS FRUGONIS CARRARENSIS FE.T", mientras en la portada lateral se localiza la firma "STEPH: S FRUGO. S CARRARIEN FECIT H. c" en la imagen de San Pablo. Ambas inscripciones hacen referencia al mismo artista.

11. Se trata de la escultura de Santo Domingo donde reza la siguiente inscripción "(IACO)BVS ANT. VS PONZANELLIVS F", localizada por Fray Vicente Díaz.

I2. Díaz, Vicente: "El retablo de Santo Domingo de Cádiz". Archivo dominicano. Salamanca, 1995. Pág. 354.

13. Remitimos al artículo de D. Jesús Espinosa Gaitán publicado en el n²9 de este mismo boletín. 